International Journal of Education, Learning and Development

Vol. 10, No.1, pp.24-43, 2022

Print ISSN: 2054-6297(Print)

Online ISSN: 2054-6300 (Online)

\title{
THE ROLE OF NGOS IN PROMOTING EDUCATION: SUCCESSES AND CHALLENGES
}

Fawzia Reza, Ed.D.

American College of Education

Fawzia Reza (2022) The Role of NGOs in Promoting Education: Successes and Challenges, International Journal of Education, Learning and Development, Vol. 10, No.1, pp.24-43

\begin{abstract}
Universal basic education is a key requirement for social justice, but it must be developed and delivered in a culturally sensitive manner. Non-Governmental Organizations (NGOs) play a very significant role in the education sector in many developing countries. The primary focus of this paper is to understand the role of six specific NGOs (in Bangladesh, Pakistan, Thailand, Cambodia, India, and Malawi) in promoting education in developing countries and explore their successes and challenges. Based on their experiences, the author has proposed certain strategies that might assist $N G O s$ who operate in other countries, and even educators in the public and private sectors in all developing countries, to ensure that all children receive quality primary and secondary education. Policymakers, Non-Governmental Organizations, and school administrations might be able to leverage the findings to better advocate for universal access to quality education in their home countries.
\end{abstract}

KEYWORDS: Non-Governmental Organizations (NGOs), literacy, developing countries, education

\section{INTRODUCTION}

Recommendations and even directives regarding seeking out and encouraging education are pervasive throughout human history. For example, as early as the seventh century AD, the Islamic prophet, Muhammad, has been famously quoted as saying "Seeking Knowledge is an obligation on every Muslim." Within European societies, similar encouragement is found starting in the Middle Ages. Early European settlers in the North American continent often quoted biblical verses to promote moral education among young children. Bishop Johann Comenius (1592-1670) advocated for education for the rich and poor and the philosopher John Locke (1632 -1704) taught that a child is like a blank slate and the environment is responsible for molding his personality (Johnson, \& Reed, 2011; Crain, 2015). Locke wrote against authoritarian regimes and taught that power should be shared by all members of society. Many early educators believed that the aim of education is to impart moral education to students and Piaget (1896-1980) and Kohlberg (1927-1987) even considered that cognitive development was directly linked to moral development (Weber,

@ECRTD-UK https://www.eajournals.org/

https://doi.org/10.37745/ijeld.2013 
International Journal of Education, Learning and Development

Vol. 10, No.1, pp.24-43, 2022

Print ISSN: 2054-6297(Print)

Online ISSN: 2054-6300 (Online)

1984; Crain 2015). These educators and philosophers believed in the value of education to impart knowledge and become skillful and moral citizens.

An educated population is now acknowledged as the backbone of any country and serves as the foundation for the development of a nation (Hussain, 2013). Primary education, which is at the base of the pyramid of education, is one of the basic human rights, considered essential for greater economic growth and development (Patrinos, 2016; Ventura, 2019). While this essential component of human capital growth establishes the foundation for any nation's prosperity, in many countries, especially in the developing world, this basic right is not appropriately recognized or encouraged.

\section{LITERATURE REVIEW: INTERNATIONAL INITIATIVES TO DEVELOP EDUCATION}

Many action plans have been proposed to encourage education in developing countries. For example, in 1990, 1,500 delegates from 157 countries participated in the Jomtien Declaration Conference (also known as the World Declaration on Education for All: Meeting Basic Learning needs) held in Thailand to promote universal elementary education (Deep, 2017). Article 2 adopted by the members of the Conference states that the goal of education "requires more than a recommitment to basic education as it now exists. What is needed is an "expanded vision" that surpasses present resource levels, institutional structures, curricula, and conventional delivery systems while building on the best in current practices." In 2000, 164 countries again participated in the Dakar Framework for Action, which proposed that six education goals should be universally achieved by 2015 (Piseth, 2020). These included providing quality early childhood education, free universal primary education, equitable access to resources for young and adult students, improving the adult literacy rate (especially for women), gender equality in education (ensuring both boys and girls have access to education) and ensuring excellence and quantifiable growth in learning outcomes. The Dakar Framework also proposed 12 strategies to achieve these goals. The Incheon Declaration for Education 2030: Towards inclusive and equitable quality education and lifelong learning for all, adopted in May 2015 by over 1,600 participants from 160 countries, proposed a new set of goals for education for the next fifteen years (Akkari, 2018). This new framework is divided into three sections. The first outlines the vision, rationale, and principles of Education 2030. The second describes the global education goal and its associated seven targets and three means of implementation, as well as indicative strategies. The third proposes a structure for coordinating global education efforts, as well as governance, monitoring, follow-up, and review mechanisms. The Incheon declaration also examines ways of ensuring that Education 2030 is adequately financed and outlines the partnerships needed to realize the agenda at country/national, regional, and global level (Education 2030).

Despite global commitment, and proposed reforms to reduce the educational gap between developed and under-developed countries, developing countries often struggle to enroll

@ECRTD-UK https://www.eajournals.org/

https://doi.org/10.37745/ijeld.2013 
students in schools. The Global Partnership for Education reports that "one in 10 children worldwide do not have access to primary school" (Global Partnership, 2014). According to them, there has been a reduction in the aid that was provided for children to receive basic education, which has constrained successful implementation of the millennium goal. Although the vision and goals of the proposed reforms/declarations are laudable, to successfully implement these goals, we first need to use a microscopic lens to understand the challenges faced by organizations who are attempting to provide educational within developing countries.

Universal basic education is a key requirement for social justice, but it must be developed and delivered in a culturally sensitive manner. NGOs now play a very significant role in the education sector in many developing countries. The primary focus of this research is to understand the role of six specific NGOs (in Bangladesh, Pakistan, Thailand, Cambodia, India, and Malawi) in promoting education in developing countries and explore their successes and challenges. Based on their accounts, the author has provided recommendations to assist educators in the public and private sectors in all developing countries as well as NGOs who operate in other countries, so that all children receive quality primary and secondary education. Policymakers, Non-Governmental Organizations, and school administrations might be able to leverage the findings to better advocate for universal access to quality education in their home countries.

\section{THE ROLE OF NGOS TO PROMOTE EDUCATION IN DEVELOPING COUNTRIES}

Developed countries such as the USA, UK and France often have resources and enforceable requirements that yield virtually universal enrollment rates. However, school enrollment often lags in developing countries, for example in South Asia, South East Asia, and Sub-Saharan Africa. Children in these countries might not have appropriate resources or even access to schools that can provide them basic education. Within many developing countries, education is imparted through many sources including public or government, private, and non-government organizations (NGO). The government or public sector is often controlled by the administration of the country and can be resource constrained or poorly staffed and managed in developing countries (Hillman, \& Jenkner, 2004). The private sector is usually driven by profits and charge high fees that are out of the reach of the poorer segments of the population. In contrast, NGOs often subscribe to altruistic values, funded by worldwide contributions, and seek to serve as catalysts for promoting sustainable educational development for everyone within the country they serve. The functions and characteristics of NGOs can vary according to the needs of the different regions and societies they serve.

It is appropriate to digress just a bit to trace the evolution of NGOs and how they have become relevant. Records describing humanitarian work can be traced back to 1,400 BC, when stone miners in ancient Egypt collected funds to help individuals of mining accidents

@ECRTD-UK https://www.eajournals.org/

https://doi.org/10.37745/ijeld.2013 
(Dang, 2009). Records of NGO's can be traced back to 1807, after the slave trade was abolished by the British. This prompted the formation of several non-profit movements who addressed issues related to abolishing slavery and attempted to improve the conditions experienced by slave labor (Potapkina, 2006). Organizations such as Save the Children, The Red Cross, and International Rotary Clubs soon followed, and began to focus on other humanitarian causes. After World War II, NGOs started expanding and have become advocates for social change around the world (Dang, 2009). NGOs are now gaining widespread attention because they are often viewed as alternative resources that can promote greater awareness, change and development in societies that are underserved or facing challenging issues that affect their quality of life.

\section{METHODOLOGY}

A qualitative study design was utilized to explore the role of six NGOs in promoting education in developing countries, the successes, and challenges that they face. The NGO's were selected, based on geographical diversity, established initiatives in promoting education in developing countries, and willingness to participate in the proposed study. Interviews to collect data were conducted with the founding partner/s and the principal, teacher or a representative designated by the NGO via Zoom at a time that was convenient for them.

The researcher was previously aware of two NGO's who she thought would be interested in participating in a study of this nature. On this basis, she proposed and received Institutional Review Board (IRB) approval from her sponsoring institution. She formally contacted these organizations to confirm they would like to participate in the study. The consent forms explicitly shared the purpose of the research and the potential risks and benefits of participating in the study. After she received the signed consent forms, she followed up with them for a date/time for the interview. The researcher informed the participants that pseudonyms would not be used, and the interview would be recorded for accuracy purposes. Once the interview with the founding members had been completed, the researcher requested them to identify principals or designated representatives from within their organization for additional questions related to how the initiatives are being implemented.

The researcher then contacted the representatives of the NGOs who were identified by the founders and sent them a consent form (similar to the form that she had previously sent the founders) to review and sign. Once she received the signed forms, she then asked them to suggest a time that was convenient for them to be interviewed. Before starting the interview, the researcher briefly explained the purpose of the study and informed the participants that the interviews would be recorded, and that pseudonyms would not be used. She also told the participants that the study was voluntary, and they did not need to answer any question that they were not comfortable with. 
International Journal of Education, Learning and Development

Vol. 10, No.1, pp.24-43, 2022

Print ISSN: 2054-6297(Print)

Online ISSN: 2054-6300 (Online)

The researcher also asked the founders if they were aware of any other NGO's who would be willing to participate in the study, a snowball sampling approach to complete interviews with the proposed number of organizations within the IRB approval

\section{ESTABLISHING METHODOLOGICAL RIGOR}

The researcher utilized the following methods to verify the accuracy of the data collected and confirm that the interpretation and analysis is consistent with the participants' experiences.

Member-checking. According to Birt et al., (2016), member checking allows findings to be shared with participants to check for accuracy of their responses and interpretation. Accordingly, the researcher provided the transcript and a summary of the analysis relevant to their NGOs to her study participants to allow them to verify the information and provide feedback regarding the researcher's interpretations.

Thick description. According to Linclon and Guba (1985), transferability and therefore, external validity, can be achieved through a thick (i.e. rich) description. The researcher designed the interview questions so that the participants could provide insightful and comprehensive responses regarding their efforts in promoting education in developing countries. This enabled researcher to understand the successes and challenges that are faced by NGO's serving in different parts of the world in a rigorous manner.

\section{DESCRIPTION OF THE NGOS AND STUDY PARTICIPANTS}

Six NGOs were ultimately selected for the study. All work in developing countries to promote education and provided rich (thick) descriptors of their approach and why they felt it was necessary to work in their focus country. A description of each NGO, and the founding member and representative interviewed for this study appears below.

Organization 1: Speak Up for the Poor. Speak Up for the Poor aims to empower girls in Bangladesh by providing them access to education. They list three primary goals on their website; Homes, where they provide young women a safe space, where they can pursue their dreams to receive quality education and be insulated from potential exploitation; Education, wherein they provide girls with basic knowledge and help them get professional training so that they can serve their communities and country; and Justice, wherein they partner with the judiciary system to handle cases related to illegal child marriages, kidnapping, rape and other types of sexual abuse and harassment issues. These issues are relatively common in Bangladesh. The founder and international director of this NGO, Troy Anderson, has a law degree from the University of California, Los Angeles, and has also served as a Deputy District Attorney with the Los Angeles County justice department. He selected the name of his organization to highlight their mission to advocate for justice and access to basic rights for the poor and marginalized. Troy shared his reason for the

@ECRTD-UK https://www.eajournals.org/

https://doi.org/10.37745/ijeld.2013 
creating the organization as, "I could work through the organization as a lawyer one day on those issues of human trafficking, forced prostitution exploitation of minors."

The interview to explore how the mission of the organization is being implemented was conducted with Pitar Sen, the Girls Education Program (GEP) Field Director for Speak up for the Poor. He manages 55 teachers and 17 staff members who report to him in the field office in Bangladesh and oversees 30 villages serving more than 1300 girls. In his interview, he explained that the girls served by his department all live at home. This is different from a college or dormitory, in traditional educational settings. He decided to join this NGO because he wanted to help underprivileged girls who do not have proper education and to change the mentality of the "people who believe that girls are only for marriage and baby production."

Organization 2: Developments in Literacy. Developments in Literacy (DIL) has a fortuitous acronym. In the Urdu language, dil means heart, and being big hearted very appreciated in Pakistani society. This NGO provides low-cost but high-quality education to children across Pakistan. Their mission statement highlights that it is necessary to provide quality education to all children in Pakistan, so that they have an opportunity to reach to their full potential and become productive members of the society. DIL has demonstrated their dedication by creating an organization that is transparent in their dealings and funding and has previously received a 4-star rating from Charity Navigator which highlights the efficiency of this organization. Fiza Shah is the Founder \& CEO of Developments in Literacy (DIL). She founded the NGO in 1997, after she recognized that the public and private sectors were unable to provide quality education to underprivileged children in Pakistan. Under her tutelage, DIL has flourished and successfully educated thousands of children with quality education across Pakistan. Fiza shared that "Pakistani Americans move away from Pakistan they come to foreign land they do take away resource that the country has actually invested in them... so I felt that the best way I could give back to Pakistan was by you know, giving back that what I owed them, and the best way was through education."

The interview to explore how the mission of DIL is being implemented was conducted with the principal of a school principal funded by the organization, Kiran Zia. Kiran initially joined DIL as an IT teacher. However, after she was hired, she realized that there was a lot that she did not know. According to Kiran, "I learned a lot during training change my life in also give me a passion for never giving up." She currently oversees their Rehmat Chowk Campus in Karachi, Pakistan.

Organization 3: Creative Life Foundation. Although education is free in Thailand through the 12th grade, many children drop out before the 9th grade to secure menial jobs. Many are also sexually exploited. Creative Life Foundation was created in 2013, specifically to assist women and vulnerable children who are at risk of "being caught up in

@ECRTD-UK https://www.eajournals.org/

https://doi.org/10.37745/ijeld.2013 
the commercial sex industry "in Thailand. According to the co- founder, Tim Hupe, he created the NGO "to connect vulnerable and marginalized children and parents in urban and rural Thailand to resources that will create a path to freedom and prevent human trafficking." By providing them education, the foundation hopes to break the cycle of poverty and from being exploited.

The interview to explore how the mission of Creative Life Foundation is being implemented was conducted with a project leader, Yadfon Boonlab. Yadfon described how the Karen tribe people, who live in the outskirts of Thailand are not considered Thai and are stateless. The Karen Hill tribe originated in Tibet and its members have moved to areas alongside the Thai-Myanmar border, including Chiang Mai, Chiang Rai, with some presence in central Thailand. Many of these people marry early so that they can help in the family farms. Since they do not have easy access to education, the Creative Life Foundation and other NGOs are promoting opportunities for this marginalized community.

Organization 4: Love Without Boundaries. In 2003, a boy was saved in China following a successful heart surgery. This prompted the idea of creating an organization where dedicated individuals would come together and create a better world for everyone. Love Without Boundaries was created to provide "hope and healing to vulnerable children, and their underserved communities, through education, foster care, healing homes, medical care, and nutrition programs. The organization now has branches in Cambodia, China, India, and Uganda. Sokleng In serves as the director of the Cambodia program. His "mercy ministry" previously provided education to children in remote areas. He shared how he became involved with Love without Boundaries; he had participated in a research study on human trafficking in Thailand and the researcher connected him to the Love Without Boundaries Organization.

The interview to explore how the mission of Love Without Boundaries is being implemented was conducted with an education manager Leat Lann in Cambodia. Leat has been working for Love without Boundaries for a few months. She joined the organization because she feels that the mission is "really helpful" and they assist the "Cambodian kid who is abandoned or fallen in a situation that is hopeless."

Organization 5: Pahal. Pahal means initiative in Hindi. Lakbir Singh, the founder of the NGO, explained that their primary mission is to serve humanity. The organization works on different projects to help local communities, including projects in education, health, and the environment. During the final editing of this paper, the author learned that Mr. Singh passed away in 2021. However, his interview and member checking of the transcript had been completed before he passed away. Lakbir was a professor, activist, and social worker. He explained that the mission of his NGO is to "create a holistic society... where all the needs of a person" are met. Pahal aims to educate the citizens with measures to circumvent the degradation of the environment in India. To achieve their goal, the organization meets

@ECRTD-UK https://www.eajournals.org/ https://doi.org/10.37745/ijeld.2013 
with school and college students they promote to advocate for causes such as conserving water, reducing air pollution and carbon emissions, and the preservation of biodiverse regions.

The interview to explore how the mission of Pahal is being implemented was conducted with a Harvinder Kaur who worked with her late husband (the founder of Pahal). Harvinder serves as the principal of the Nirmaan school that Pahal operates and motivates young girls to take care of their hygiene and health and at the same time provide them education for a better and satisfying professional career.

Organization 6: Teach the World Foundation. The overarching mission of the Teach the World Foundation is to enhance literacy through digital technology. This NGO has partnered with some of the poorest countries with the highest illiteracy rates including Malawi, Pakistan, and Bangladesh. The organization runs three types of digital literacy programs: In-school, micro-school, and smartphone to develop literacy. Shafiq Khan is the president and the co-founder of Teach the World Foundation. He shared that he and his partner, Mr. Imran Sayeed were enjoying successful careers when they decided that "we've done well in the world it's been a gift and we want to start giving the gift back." Therefore, they started their NGO to create social impact in "areas where impact is highest" and focused on education. The mission of their NGO is to establish and deploy effective and scalable models of literacy and learning by leveraging the power of digital technology.

Ms. Susan Cabon joined Teach the World Foundation a few years ago. She serves as the country manager and since Teach the World sponsors one of the centers at Joshua, she was able to provide some information regarding how literacy is promoted using the tablets provided by the NGO. Susan previously worked as a teacher in an international school for 20 years and wanted to and explore if she "could do something that was more connected to most of Malawi, rather than the kind of elite international school." At a friend's recommendation, she joined the Joshua Orpah and Community Center, which has 17 preschool/childcare centers near Blantyre.

\section{FINDINGS}

Seven broad themes emerged from the interviews conducted for this study. 1) What motivated the founders to create the NGO; 2) The successes they have achieved in promoting education in their chosen countries; 3 ) The challenges that they face to promote education in their chosen countries; 4) How they promote parental involvement; 5) Do they offer career advice to their graduates; 6) Do they sponsor professional development activities for their staff and teachers; and, 7) Are they familiar with the UN millennial goals and how they meet these within their organization. 


\section{MOTIVATION TO START THE NGO}

The term motivation is derived from the Latin word motivus, which means a moving cause (Encyclopedia Britannica, 2013). There must be an incentive to move or create a change, which can be extrinsic or intrinsic (Bloisi et al., 2007). Extrinsic motivation may be due to a desire to get promoted or get a pay raise. Intrinsic motivation is a genuine concern to resolve a concern and contribute towards creating a better world. A study by Cappellari et al., (2011) on 1400 Italian workers demonstrated that intrinsic motivation plays a major role in what makes people to dedicate themselves into voluntary activities. Non-profit organizations, including NGOs, are often less capital intensive and more labor-intensive due to the nature of their work. Therefore, intrinsic motivation is their primary driving force, and determines whether the organization will make progress towards achieving their vision. The researcher attempted to better understand what motivated the founding participants to create their organization.

Although all NGOs in the study focus on providing educational opportunities to marginalized populations, the specific reasons the founders originally created their NGO varied. Troy shared that his primary motivation was to create a mechanism through which "they can empower girls so that they're never susceptible to being trafficked are forced into child marriages." Tim shared similar reasons for starting his NGO, to "prevent human trafficking." As these NGOs matured, it became clear that providing better educational opportunities was the most effective way of empowering those most vulnerable to exploitation. In contrast, Fiza, Sokleng, Lakbir, and Shafiq were motivated to start their NGOs after recognizing that existing educational opportunities in many countries were not adequate and they could effectively supplement available opportunities for marginalized populations. Shafiq shared, "if you're going to do it for social impact let's go find the areas where impact is highest... and supplement or make up for the deficit that you have in the education capabilities of largely the government."

\section{SUCCESSES IN PROMOTING EDUCATION}

NGOs supplement essential services and provide humanitarian assistance in many underdeveloped countries. Because they are usually funded by charitable donations, they typically have efficient and effective organizational structures, and access to donorresources to promote education, provide better health care, and help alleviate poverty through sustainable development. Asamoah (2003) shared how work performed by NGOs is especially effective and needed where governmental funds are scarce and the country has limited resources due to the low level of per capita income which restricts the ability of people to maintain a decent living for themselves and their families. In recent years, NGOs have emerged as successful in promoting education by supplementing and collaborating with government efforts.

@ECRTD-UK https://www.eajournals.org/

https://doi.org/10.37745/ijeld.2013 
International Journal of Education, Learning and Development

Vol. 10, No.1, pp.24-43, 2022

Print ISSN: 2054-6297(Print)

Online ISSN: 2054-6300 (Online)

The researcher wanted to explore the effectiveness of the NGOs in this study in promoting education within the countries they operate in. Troy shared how there has been a reduction in child marriage rate in the villages that they work, and more girls are completing higher education. He explained that while their organization operates primarily in Bangladesh, they also "have small projects that we fund in Cambodia and in Lebanon for Syrian refugee girls." When he was a law student and even working as a lawyer in the early days he was very interested in "helping get girls and young women out of trafficking or out of brothels and there's a lot of need for that those kind of removals after care. But over time, I realized that a lot of the, what, is needed, and perhaps $95 \%$ of the money and emphasis needs to go into preventative side so that you can empower girls so that they're never susceptible to being trafficked or are forced into child marriages or into other exploitative situations." While Speak up for the Poor does not build schools because the government funds free public education for children through 12th grade, they provide "these girls the academic support they need to stay in school, giving them books school supplies tutoring."

Fiza explained that DIL schools are "producing kids who are you know who have the required soft skills." She further explained, these include "the critical thinking, problem solving, communication and all those skills that are required in the workforce, because in the end, education is a conduit to success." Another success she shared is the use of Technology Enabled Academic Learning (TEAL). TEAL based learning is student centered and is imparted through videos that students watch using a tablet. "This frees the teacher from standing in front of the board and teaching in a very passive manner." Instead, the teacher is involved with the student and the can view the "post test results in real time so she knows exactly who got it who didn't get it."

Tim shared that his NGO is promoting "education as the way to prevent both break cycles of poverty, but then also prevent some of these of root causes of issues like human trafficking." English is the third language for some students they serve, and he is proud that two of his students have progressed sufficiently that they are now qualified for and attending an "International school." Initially, his primary mission was to provide educational materials to children who were begging on the streets to provide for their families or homeschooling a few students. However, as Tim explained, "you know what we were doing was good, but it wasn't you know it wasn't effective, you know and, and so we wanted to try to do something to remove you know this handful of children that we knew that we're putting themselves at risk every day." Therefore, Creative Life Foundation began to partner with local Thai leaders and "expanded what we're doing as far as homeschooling into the scholarship program for at risk youth within the city." After one of his staff members moved to Chiang Mai, in Northern Thailand, they are getting more involved with hill tribe communities because "that hill tribe specifically girls and women were also high risk for trafficking, because they weren't documented and so, so this right to citizenship, you know got on our radar as well as girls specifically who weren't finishing 
school therefore getting married at a really young age, and so that was something that we wanted to use education to eliminate as well."

Sokleng described how Love Without Boundaries is promoting higher education and "providing scholarships so they can go to university." He explained that since many parents work to earn their basic livelihood, young children are often left to the care of their older siblings. Some students would even come to school with their younger siblings and could not focus on studies. To address this issue, "the organization created a baby care" where "older children can drop their babies to the baby care and then they can focus on learning."

Lakbir shared how his NGO is providing "technical" education to students. He explained that "Child Labor is a big challenge in India. You see, there are many places where children are working. In stalls, dhabbas (local, informal restaurant), workshops, even in factories. The girls are working in houses with their parents for cleaning the house. Their NGO is "handling two child Labor schools where in one school 50 children, boys and girls who belong to some of them are laborers and some of them belong to a labor background" are being taught.

Shafiq described an experiment by his NGO to determine if the tablets were in fact making a difference. He enrolled "completely illiterate kids, who in $95 \%$ to $96 \%$ of the case(s) also had completely illiterate parents" in their experimental group classroom and provided these children "tablets and had them learn from them." He also had a "control group which was from the same community, same aged children, getting an education in a traditional setting and made a comparison." Results demonstrated that "on average the learning gains were twice as much as the kids who were getting a traditional education." He attributed two reasons for this "the quality of the application, the quality of the software and the in the engagement that it generates", and "the quality of education provided at the government schools in particular is so bad that you know our kids really outperform." Susan agreed "NGOs are useful to Malawi, because they provide a variety of kinds of early childhood education, but the government doesn't provide any so education in Malawi starts when children are six that standard one that's the beginning of primary."

\section{CHALLENGES TO PROMOTE EDUCATION}

Troy, Fiza, and Tim shared that one of their primary challenges is obtaining sustainable funding for ongoing initiatives within their respective countries. Tim explained how the current pandemic has created a significant barrier in funding for his organization, "money does create a barrier, as far as how many kids can be enrolled in the program as far as how much resources, we can actually provide it depends on how funded we are..." He further added, "this [Covid and the inability to fundraise in person] took a big hit for us and we're small, as it is." 
Fiza also shared that finding quality teachers can become a challenge because, "you have to make them unlearn and then teach them again." Sokleng described poor school attendance as an ongoing challenge. Some parents cross the Cambodian border to go to Thailand and take their children with them. In Thailand, these children are used for begging, ... for selling flowers... or they abduct children.”

Lakbir discussed how extreme poverty can prevent some from continuing their education, despite the support provided by his NGO. For some people, "to earn bread today is more important than to get knowledge to get study for the future." Shafiq added that some of the challenges in promoting education are "technology barriers, the broadband, for instance, is not uniform." He added, "the commitment to learning or understanding of the value of learning is one of the biggest barriers."

Susan feels that language barriers can also affect the quality of education they can provide, "I think one of the tidbit difficulties that we have with the digital learning is only that when they [children] go to school, they learn in English, and they don't speak English at home." The software includes items that children might not be familiar with, so it takes additional time for teachers to explain it in their native language. She provides examples of words such as hamburgers and spaghetti are very common to the students in the west. This may not be the case with students in Malawi who adhere to simpler diets of "maize and a small vegetable every day of their lives."

\section{PARENTAL INVOLVEMENT}

Parents are their children's first teachers and remain central to their learning experience throughout the school years. While some parents can work with their children effortlessly, others face challenges, including language barriers, resource constraints, or an education deficit, which preclude them from effectively coaching and mentoring their children. Developing parental self-efficacy regarding child-rearing can make them feel comfortable and confident in becoming more involved in their children's schooling. The researcher explored whether the NGOs facilitate parental involvement (for example via dedicated resources or training/workshops) and how often they reach out to parents.

Speak Up for the Poor provides training meetings every month for parents. Troy shared that these meetings are typically attended by women since "mom is at home and the dad is working in the field or, you know, driving the rickshaw or whatever his, labor is some most dads are not available during the day." Pitar corroborated him, "every month, we have a parent's meeting in every village" ... although it is called "parents meeting but it's mostly mothers right yeah 95\%."

Developments in Literacy also promotes parental involvement via regular meetings. Fiza shared that during harvest season, older girls start missing school. Teachers and administrators will contact parents if they see that their children are not attending school

@ECRTD-UK https://www.eajournals.org/

https://doi.org/10.37745/ijeld.2013 
and will conduct a meeting "either collectively or separately" to ensure that students attend more regularly. Kiran, stated that "In our NGO, students are not only connected with us, the parents are also connected", she emphasized that she holds regular meetings with parents.

Creative Life Foundation recognizes that many parents are unable to help their children or become involved in their school because they are not educated. To address this, Tim proposed an adult literacy program because "they [parents] see the doors that will open once they can read and write and once they see the value of education." Yadfon added that their literacy program helps parents to develop linguistic skills since "most of them are couldn't speak the Thai language as well."

Love without Boundaries has an open-door policy wherein parents can come and ask questions that they might have regarding their children. However, they do not offer any training or workshops. Leat shared that their teachers are always willing to provide "advise" to parents. Pahal has tried to hold meetings but very few parents showed up for these. Harvinder explained, "parental involvement is very less because they're [parents] laborers they are busy." To promote greater involvement and meet the parents, they invite parents to their school and offer gifts on local festival days, e.g., "Divali, Lohri."

Parental involvement is extremely important to Teach the World. As Shafiq explained, some parents are difference makers. He shared the example of a parent promoted the idea of a smart phone literacy program. They contacted the Chief Implementation Officer and Director of Operations and asked her to help with homeschooling her and some other children in their areas who were homebound during COVID. With proper scaffolding and regular check-ins with parents and students, Teach the World Foundation is promoting literacy to a wider audience. However, as Shafiq explained, day-to-day constraints can make it difficult for most parents to become more involved "while it is important, I mean to me" and is "a crucial differentiator, it is very unfortunate that with the people that we are working with in the vast majority of cases that can is at best, involved in, you know seeing the children off to school getting them ready and so on."

\section{CAREER ADVICE TO GRADUATES}

In a report for the Organization for Economic Cooperation and Development (OECD, 2018), Musset et al., highlight the benefits of career guidance and counseling for individuals and for the society. The authors explain that "it helps individuals to progress in their learning and work, but it also helps the effective functioning of the labor and learning markets, and contributes to a range of social policy goals, including social mobility and equity." Many young individuals, particularly those from disadvantaged backgrounds, often lack resources or networks to obtain information on where and how to apply for adequate positions. The researcher solicited responses from the participants regarding how their NGOs address this need. 
Troy explained that although Speak Up for the Poor helps their students to achieve higher education, due to shortage of staff, they are unable to assist them with job placements. Pitar elaborated that they help their students with their resumes and coach them how to give interviews. Fiza shared that DIL cannot place their students into jobs but "we try to connect them with places where they can get that." Kiran confirmed that the NGO conducts "career guidance sessions and many other sessions and make our hub for our graduates when we find or we when we hear about any job requirements or we just inform our graduates to apply there or things like that." Tim explained that Creative Life Foundation does not provide career placement services "for all students, because not all students are necessarily looking for that." However, the NGO will help students who ask for assistance. He provided an example of a student who was looking for a job and they connected them to a coffee shop. The owner of the coffee shop was so impressed with their work that she "actually became a board member because she loves what we do." Yadfon confirmed that "we connect them to the company or to the job that we can provide them."

Sokleng shared that Love without Boundaries does not have "people or don't have resources to do this [provide career placement support] yet." Leat agreed that while they indirectly prepare their students for jobs by providing them with education, they do not have any mechanism specifically "for a job." Pahal also does not provide career advice to their students and Harvinder explained that because they serve young children, "there is no job, so we can't." Shafiq and Susan shared a similar constraint. Teach the World Foundation works with young children and therefore, there are no opportunities (or demand) for career advancement or placement.

\section{PROFESSIONAL DEVELOPMENT OPPORTUNITIES FOR STAFF AND TEACHERS}

Professional development training is essential for educators to understand the latest research and best practices regarding how to scaffold student development. Teacher who are well trained can achieve better academic outcomes and create a student-centered classroom environment that promote the 4 competencies identified in the Partnership for $21^{\text {st }}$ century learning (P21). The 4 C's include Critical Thinking, Communication, Collaboration, and Creativity.

The researcher asked the designated representative from each NGO whether they were provided formal training and responses varied. Kiran shared DIL provides them "training at every stage of our work now, so the resources to work effectively with our students" Yadfon (Creative Life Foundation) shared that "like every year and then, when we have an extra training, we always have a training and more like do things to use resources." Leat (Love Without Boundaries) receives training from her director or boss regarding "child protection" and "school policies". 
In contrast, Pitar (Speak up for the Poor) and Harvinder (Pahal) do not receive any specific training or workshops. Shafiq shared Teach the World Foundation "have a five-day training program in which we actually train a facilitator to begin to run this [software program]. We offer them you know troubleshooting support ongoing which you have to". Susan explained that from "teach the world, we received the guide, the training handbook" They "have a regular meeting every week with teach the world" and further elaborated, that "they receive training from the foundation on how to conduct assessments ... (but) the people from the office receive that training we don't ask the caregivers to do the digital assessments".

\section{MEETING UNITED NATIONS MILLENNIUM GOALS}

Even though policies and reforms have been developed to address and promote the UN millennium goals in many developing countries, developing effective implementation strategies is still necessary to achieve these goals. All participants unanimously agreed that they were aware of the UN Millennium goals, specifically as they relate to education. In this context they highlighted two specific goals as especially relevant, MDG-2 (Achieve Universal Primary Education) and MDG-3 (Promote Gender Equality). All NGOs. are working towards achieving these goals. Tim elaborated how the connection between MDG-2 and MDGG-3 and how his organization is furthering progress in these, "like by supporting you know girl's education, I believe you know that's directly impacting gender equality". He added, "as far as the providing access to education that's directly, tackling root causes of poverty and what keeps people in poverty, and so you know, poverty is one of them".

\section{DISCUSSION}

Based on the data collected and analyzed, the researcher revisited the primary purpose of the study which was to understand the role of six specific NGOs (in Bangladesh, Pakistan, Thailand, Cambodia, India, and Malawi) in promoting education in developing countries and explore their successes and challenges. The researcher analyzed their success and challenges and developed recommendations for sustainable practices based on the study findings.

\section{SUSTAINABLE SOLUTIONS}

The Bruntland Commission Report defines sustainable development as meeting the needs of the present without jeopardizing the ability of future generations to meet their needs (United Nations General Assembly, 1987, p. 43). Ravindranath explained how sustainable development can be applied to education, is applicable which states, "all aspects of public awareness, education and training provided to create or enhance an understanding of the linkages among the issues for sustainable development and to develop the knowledge, skills, perspectives and values that will empower people of all ages to assume responsibility for creating sustainable futures". (Ravindranath, 2007, pp. 191-192). 
For an NGO to be successful, their efforts and solutions must be sustainable. Therefore, all NGOs require continued and consistent funding from their donors, which can be a significant challenge. Fiza shared how DIL has modified their approach to take advantage of existing infrastructure, "we are going to start now adopting government schools and bringing about change there because we feel that that is the most sustainable solution". Pakistan has many schools that physically exist but are either poorly funded, suffer from poor administration, or do not have appropriately trained and committed teachers. The government-NGO partnership she described will relive DIL from constructing new schools and allow them to work with existing resources to improve educational outcomes. Troy from Speak Up for the Poor shared a similar strategy, "in some areas we will partner directly with the school, rather than having even the tutoring need to be at our centers, having some of the tutoring be at the schools."

Tim explained that Creative Life Foundation partners with schools to provide books and supplies. For example, they conduct an "English camp, wherein they bring their own materials, because they understand that it might be challenging for schools to supply additional resources and "we don't want to take from them." Teach the World sponsors different types of programs to develop educational literacy. In their school programs, students attend school in person. They also sponsor micro-schools, which Shafiq explained as "you rent a room in a community that has really badly short of schools. We hire a mom usually moms are good managers, ideally, we want mom who is also a teacher. And then we give her 25 tablets and set her up with solar and everything right in the room that we rented, so there is a fan and the light, and you know clean nice clean room in the bathroom." They have also recently started the smart phone program in which children learn by downloading an app on their parent's smart phones. According to the Teach the World Foundation website, "Our facilitators have regular check-ins with parents and students take weekly online quizzes to reinforce learnings." The NGO currently only has the smart phone and micro-school programs available in Pakistan and Bangladesh.

The current pandemic has reiterated the importance of sustainable practices. Susan explained how "during lockdown we sent the tablets out with the caregivers to various people's homes" This simple step helped children continue receiving some education and avoid what some people call, Covid-slide (a metaphor based on Summer slide, in which children from low socio-economic backgrounds lose a month of academic learning each summer).

Even if schools are accessible, well-funded, and staffed with qualified teachers, efforts to promote education can only be successful if local students demonstrate interest and enroll. For example, females are discouraged from attending school in many developing countries. Troy described that one of the ways Speak Up for the Poor creates greater opportunities for girls is by getting "some after school support that they [students] need. So we're working on that. But we have a close friendship with political figures with principals and

@ECRTD-UK https://www.eajournals.org/

https://doi.org/10.37745/ijeld.2013 
teachers at every school that our girls go." This helps foster and promote greater interest in girl's education. Love Without Boundaries develops greater interest in enrollment by meeting the nutritional needs of underprivileged students. Leat explained "you know when the kid come to the school parent will expect who will feed the kid or who will take care of the kid.... we provide that warm feeling to the parent that we will look after the kids and the kids will have some food at school."

\section{PROFESSIONAL DEVELOPMENT AND CULTURALLY RELEVANT PEDAGOGY}

Promoting growth and development opportunities is a perquisite for developing committed and qualified teachers. Bredeson (2002) highlights the importance of professional development opportunities for teachers as critical to the successful implementation of the various educational reform initiatives. Based on the research findings, professional development opportunities are not consistently offered by the NGOs studied.

Professional development is more effective if the content is culturally relevant. Culturally relevant pedagogy, as developed by Ladson-Billings in the 90s requires that educators actively educate themselves and their students on the personal and sociopolitical issues that impact their students, their students' communities, and the world. The NGOs in this study are active in different countries and their teachers will benefit if they are provided opportunities to develop cultural sensitivities. To be effective scaffolders of their students, the teachers must be regularly trained on how to develop cultural competence to best serve their students. This is consistent with Bochman (2011) and Broussard (2007) who highlight the significance of aligning the curriculum to the local context to achieve positive learning gains. A one size fit all approach cannot work.

\section{ENCOURAGE GREATER PARENTAL INVOLVEMENT}

Schools that develop strong partnerships and involvement of all parents ultimately provide a richer and more satisfying school experience for their students with better academic outcomes and higher student retention (Epstein, 1987).

The family systems theory views the family as an emotional unit and utilizes a systemsbased approach to describe the complex inner networking within the unit (Kerr, 2000). It is grounded in the idea that the family members are intensely connected emotionally. If teachers understand that how the connection between family members can affect their thoughts, feelings, and actions, they can create greater opportunities for family members to become involved in schools.

Families differ in terms of ethnicity, race, and culture; language; economics; gender roles; religiosity; and geographic location. Therefore, teachers should also develop cultural sensitivity to work effectively with diverse families and honor their cultural differences

@ECRTD-UK https://www.eajournals.org/

https://doi.org/10.37745/ijeld.2013 
and the funds of knowledge that they bring to our classrooms. By exploring the collective aspects of parental involvement, language, literacy, behavioral outcomes, cultural challenges, socioeconomic status, environment and emotional development in depth, educators can help prepare themselves to meet the ever-growing need of families.

While most of the NGOs in this study promote parental involvement, some do not prioritize this aspect because they feel that parents are too busy just earning a basic living. This contradicts a study by James (2008), who demonstrated that most parents he studied would participate in more school related activities if they could find the time to do so. Vassallo (2000) also agrees that time constraints can make it difficult for many parents or caregivers to regularly volunteer at school and school related activities. Given the demonstrated benefits of parental involvement in making parents stakeholders in their children's education, the NGOs might consider additional creative ways and incentives to promote parental involvement. While there is no one-size fits all model, Pahal's approach of providing gifts on festival days is a good start. Providing free meals during regularly scheduled workshops might be another option.

\section{CONCLUSION AND LIMITATIONS}

NGO's play a significant role in promoting education in developing countries and can successfully reach many children who would not have received any education without their efforts. However, they also face challenges to effectively implement educational reforms.

This qualitative study explored the roles of six NGO's in promoting education within the countries they operate in and examined the successes they have achieved and the challenges that they face. Study participants shared several effective and sustainable solutions that they have implemented with their organization to promote education in the face of limited funds. The challenges faced by these NGO's are also shared to create greater awareness and possible solutions to their issues.

Although the findings of the study cannot be generalized due to the limited sample set, the researcher included thick descriptions that explored how each NGO promotes education in their respective countries to facilitate transferability and external validity. Future studies using mixed method or quantitative methodologies should be conducted to complement the study findings.

\section{REFERENCES}

Akkari, A. (2018). International agenda education 2030: An uncertain consensus or a tool to mobilize education actors. British Journal of Educational Studies, 5(2), 1-12. Asamoah, Y. (2003) NGOs, social development and sustainability, Foreign Aid Rating. Bloisi, W., Cook, C.W. \& Hunsaker, P.L. (2007). Management and Organisational Behaviour. 2nd Edition. Berkshire: McGraw-Hill Education 
International Journal of Education, Learning and Development

Vol. 10, No.1, pp.24-43, 2022

Print ISSN: 2054-6297(Print)

Online ISSN: 2054-6300 (Online)

Birt, L., Scott, S., Cavers, D., Campbell, C., \& Walter, F. (2016). Member checking: A tool to enhance trustworthiness or merely a nod to validation? Qualitative Health Research, 26(13), 1802-1811. https://doi.org/10.1177/1049732316654870

Bredeson, P. 2002. The architecture of professional development: materials, messages and meaning. International Journal of Educational Research, 37(8):661-675.

Bochman, D. J. (2011). Interorganizational cross-cultural transformative learning: The Ghana Rural Water Project experience (Doctoral dissertation). Available from ProQuest Dissertations and Theses database. (UMI No. 3496615)

Broussard, J. T. (2007). Thinking through gender and environmental change: An ethnographic study of a development program for Chinese farming women (Doctoral dissertation). Available from ProQuest Dissertations and Theses database. (UMI No. 3286641)

Cappellari, L., Turati, G. \& Ghinetti, P. (2011). On time and money donations. The Journal of Socio-Economics, 40, 853-867

Crain, W. (2015). Theories of development: Concepts and applications: Concepts and applications. Psychology Press.

Dang, L. H. (2009). Non-Governmental Organizations (NGOs) and development: An illustration of foreign NGOs in Vietnam [Unpublished master's thesis]. Ohio University.

Deep, S. S. (2017). Seasonal migration and exclusion of children in school education. International Journal of Advanced Educational Research, 2(4), 01-07.

Encyclopedia Britannica, (2013, February). Britannica Academic edition. Britannica web site [Retrieved: 2013-02-12]

Epstein, J. L. (1987). Toward a theory of family school connections: Teacher practices and parent involvement. In K. Hurrelmann, F. Kauffmann \& F. Losel (Eds.), Social intervention: Potential and constraints. New York, NY: Walter deGruyter.

Hillman, A. L., \& Jenkner, E. (2004). Educating children in poor countries. International Monetary Fund.

Hussain, F. (2013, November 2). Backbone of society. The Nation. https://nation.com.pk/03-Nov-2013/backbone-of-society

James, M. L. (2008). Parental involvement in their child's education. (Unpublished doctoral dissertation). Capella University, Minneapolis, MN.

Johnson, T. W., \& Reed, R. F. (2011). Philosophical documents in education. Pearson College Division.

Kerr, M. E. (2000). One family's story: A primer on Bowen theory. Retrieved from https://www.thebowencenter.org/theory/eight-concepts

Lincoln, Y. S., \& Guba, E. G. (1985). Naturalistic inquiry. Beverly Hills, CA: Sage.

Musset, P., Kureková, L. M., \& Slovak Governance Institute. (2018, July 4). Working it out: Career guidance and employer engagement. Organization for Economic Cooperation and Development (OECD). https://www.oecd.org/officialdocuments/publicdisplaydocumentpdf/?cote=EDU/ WKP(2018)11\&docLanguage $=$ En

@ECRTD-UK https://www.eajournals.org/

https://doi.org/10.37745/ijeld.2013 
International Journal of Education, Learning and Development

Vol. 10, No.1, pp.24-43, 2022

Print ISSN: 2054-6297(Print)

Online ISSN: 2054-6300 (Online)

Patrinos, H. A. (2016, May 17). Why education matters for economic development. World Bank Blogs. https://blogs.worldbank.org/education/why-educationmatters-economic-development

Piseth, N. (2020, September 21). Adult education in Cambodia: Challenges and the way forward. Phnom Penh Post. https://www.phnompenhpost.com/opinion/adulteducation-cambodia-challenges-and-way-forward

Potapkina, V. (2006). The role of international humanitarian NGOs in African conflicts in the post-cold war period [Unpublished doctoral dissertation]. Masarykova University.

Ravindranath, M. J. (2007). Environmental education in teacher education in India: Experiences and challenges in the United Nation's Decade of Education for Sustainable Development. Journal of Education for Teaching, 33, 191-206.

United Nations General Assembly. (1987). Report of the world commission on environment and development: Our common future. Oslo, Norway: United Nations General Assembly, Development and International Co-operation: Environment.

Vassallo, P. (2000). Policy Analysis: More than grades. How choice boosts parental involvement and benefits children. Retrieved from: http://www.cato.org/ pubs/pas/pa-383es.html.

Ventura, R. C. (2019, September 26). The economic benefits of education. The Borgen Project. https://borgenproject.org/economic-benefits-of-education/

Weber, E. (1984). Ideas influencing early childhood education: A theoretical analysis. 